Conference Proceedings Paper

\title{
Integrative Descriptions of Three New Tardigrade Species along with the New Record of Mesobiotus skorackii Kaczmarek et al., 2018 from Canada
}

\author{
Pushpalata Kayastha ${ }^{*}$, Milena Roszkowska ${ }^{1,2}$, Monika Mioduchowska ${ }^{3,4}$, Magdalena Gawlak ${ }^{5}$, \\ and Łukasz Kaczmarek ${ }^{1}$ \\ ${ }^{1}$ Department of Animal Taxonomy and Ecology, Adam Mickiewicz University in Poznań, Uniwersytetu \\ Poznańskiego 6, 61-614 Poznań, Poland; pushpalata.kayastha@gmail.com, mil.roszkowska@gmail.com, \\ kaczmar@amu.edu.pl \\ ${ }^{2}$ Department of Bioenergetics, Faculty of Biology, Adam Mickiewicz University in Poznań, Uniwersytetu \\ Poznańskiego 6, 61-614 Poznań, Poland \\ ${ }^{3}$ Department of Genetics and Biosystematics, Faculty of Biology, University of Gdańsk, Wita Stwosza 59, 80- \\ 308 Gdańsk, Poland; e-mail: monika.mioduchowska@ug.edu.pl \\ ${ }^{4}$ Department of Marine Plankton Research, Institute of Oceanography, University of Gdańsk, Marszałka \\ Piłsudskiego 46, 81-378 Gdynia, Poland \\ ${ }^{5}$ Institute of Plant Protection - National Research Institute, Władysława Węgorka 20, 60-318 Poznań, Poland, \\ e-mail: m.gawlak@iorpib.poznan.pl \\ * Correspondence: pushpalata.kayastha@gmail.com; Tel.: +48608777235
}

\begin{abstract}
We describe three new tardigrade species from Canada, i.e., one representing Paramacrobiotus richtersi complex, the other Macrobiotus hufelandi complex and one belonging to the genus Bryodelphax. Integrative analysis is made based on morphological and morphometrical data (using both light and scanning electron microscopy (SEM)) combined with multilocus molecular data (nuclear sequences, i.e., $18 \mathrm{~S}$ rRNA, $28 \mathrm{~S}$ rRNA and ITS-2 as well as mitochondrial COI barcode sequences). Paramacrobiotus sp. nov. differs from most species of the genus by a different type of the oral cavity armature, details of egg morphology (number of areoles around egg processes and shape of egg processes) and some morphometric characters of adults (presence or absence of eyes, presence or absence of granulation on legs, dentate lunules under claws IV). Based on COI molecular data, Macrobiotus sp. nov. is most similar to Mac. canaricus Stec, Krzywański \& Michalczyk, 2018 (p-distance 17\%). Bryodelphax sp. nov. is most similar to Bry. parvulus Thulin, 1928 (p-distance $16 \%)$. Moreover, both species differs also from their congeners in some morphological and morphometrical characters of adults and/or details of eggs. Additionally, a large population of Mesobiotus skorackii Kaczmarek, Zawierucha, Buda, Stec, Gawlak, Michalczyk \& Roszkowska, 2018 was found in Canada and this is the first report of this species outside terra typica in Kirghizia. The original description of this species was based solely on the morphology. Here we provide an updated description of the species by means of integrative taxonomy.
\end{abstract}

Keywords: DNA barcoding; Eutardigrada; Heterotardigrada; Tardigrada; Taxonomy; Water bears

\section{Introduction}

The phylum Tardigrada, also commonly called water bears, inhabit terrestrial and aquatic (freshwater and marine) environments. They are found in mosses, lichens, soil, leaf litter, sediments and on aquatic plants [1-3]. Till date, more than ca. 1300 species of tardigrades have been described throughout the world [4-7]. Tardigrade fauna of Canada is rather poorly known and up to now only ca. 120 species have been reported from this region [8-9].

In this study, we applied integrative taxonomy for description of three new species from Canada belonging to Paramacrobiotus richtersi complex, Macrobiotus hufelandi complex and the genus 
Bryodelphax, and update description Mesobiotus skorackii Kaczmarek, Zawierucha, Buda, Stec, Gawlak, Michalczyk \& Roszkowska [10].

\section{Material and Methods}

Sample processing

Moss sample was collected in Banff National Park (Alberta, Canada) in March 2019. The sample was then packed in a paper envelope, dried at a temperature of ca. $20{ }^{\circ} \mathrm{C}$, and delivered to the Department of Animal Taxonomy and Ecology at the Faculty of Biology, Adam Mickiewicz University in Poznań (Poland). The tardigrade collection, extraction and mounting techniques followed the protocol of Stec et al. [11].

\section{Microscopy and imaging}

In total 171 animals and 77 eggs were mounted on microscope slides in the Hoyer's medium, and then examined under Olympus BX41 Phase Contrast light Microscope (PCM) associated with Olympus SC50 digital camera (Olympus Corporation, Shinjuku-ku, Japan).

The 60 animals and 36 eggs were prepared for Scanning Electron Microscope (SEM) analysis according to the protocol in Roszkowska et al. [12] and examined under high vacuum in Hitachi S3000N SEM.

All figures were assembled in Corel Photo-Paint 2017. For deep structures that could not be fully focused in a single photograph, a series of 2-10 images were taken every ca. $0.5 \mu \mathrm{m}$ and then manually assembled into a single deep-focus image in Corel Photo-Paint 2017.

\section{Genotyping}

Methods used to obtain voucher specimens after DNA isolation follows Kaczmarek et al. [14]. In total 10 of the specimens were used for DNA isolation. The polymerase chain reaction (PCR) was carried out for four DNA fragments with different mutation rates, i.e., mitochondrial cytochrome oxidase subunit I (COI), cytoplasmic ribosome small and large subunit components (18S rRNA and $28 \mathrm{~S}$ rRNA, respectively) and nuclear internal transcribed spacer 2 (ITS-2). We used HCO2198 and LCO1490 primers to amplify the COI gene fragment [15]. The 18S rRNA gene fragment was amplified using primers: SSU01_F and SSU82_R [16]. To amplify the 28S rRNA gene fragment we applied the following primers: 28SF0001 and 28SR0990 [17]. In turn, for the ITS-2 fragment we used primers: ITS3 and ITS4 [18]. Amplification of mitochondrial and nuclear sequences, visualization of obtained PCR product and sequencing directly in both directions was performed according to Kaczmarek et al. [19].

\section{Comparative molecular analysis}

To verify the homology of the amplified molecular markers with sequences deposited in the NCBI database, BLAST (Basic Local Alignment Search Tool [20]) searches were performed. All obtained sequences were checked for quality and consensus sequences were created for each individual in BioEdit v. 7.2.5 [20]. The COI sequences were translated into amino acid sequences to check for indels and internal using the EMBOSS-TRANSEQ application [21-22]. Finally, the the MEGA X [24] was applied to calculate the uncorrected pairwise distances (p-distances) for COI sequences.

\section{Results}

\section{Taxonomic account}

Type Locality: $51^{\circ} 24^{\prime} 21^{\prime \prime} \mathrm{N}, 116^{\circ} 14^{\prime} 27^{\prime \prime} \mathrm{W}, 1900$ m a.s.l., Canada, Alberta, Banff National Park, near east end of the Louise Lake, moss on stone, May 2019, leg. Milena Roszkowska and Łukasz Kaczmarek.

Type depositories: All type materials were deposited at deposited at the Department of Animal Taxonomy and Ecology, Institute of Environmental Biology, Adam Mickiewicz University in Poznań, Uniwersytetu Poznańskiego 6, 61-614 Poznań, Poland. 


\section{DNA sequences}

We obtained good quality sequences for the applied molecular markers:

18S rRNA: two sequences; 528 bp long;

28S rRNA: two seguences; 671 bp long;

COI: three sequences; 584-672 bp;

Based on COI molecular data, Bryodelphax sp. nov. is most similar to Bry. parvulus Thulin, 1928 (pdistance $16 \%)$.

Short diagnosis: Bryodelphax from weglarskae group. Colour light yellow. Cirri interni and externi with poorly developed cirrophores. Cirri $A$ of typical length for Bryodelphax, i.e. reaching ca. $25 \%$ of the total body length. Paired and median plates divided into anterior and posterior parts. Dorsal sculpture, visible in PCM, composed of dark granules and white pores. Venter with three rows of greyish plates (III:2-2-1). Spine on leg I absent. Papilla on leg IV present. Dentate collar absent on leg IV. Claws slender, claws IV always slightly longer than claws I-III. External claws smooth, internal ones with a small spur pointing downwards and placed very close to the claw bases.
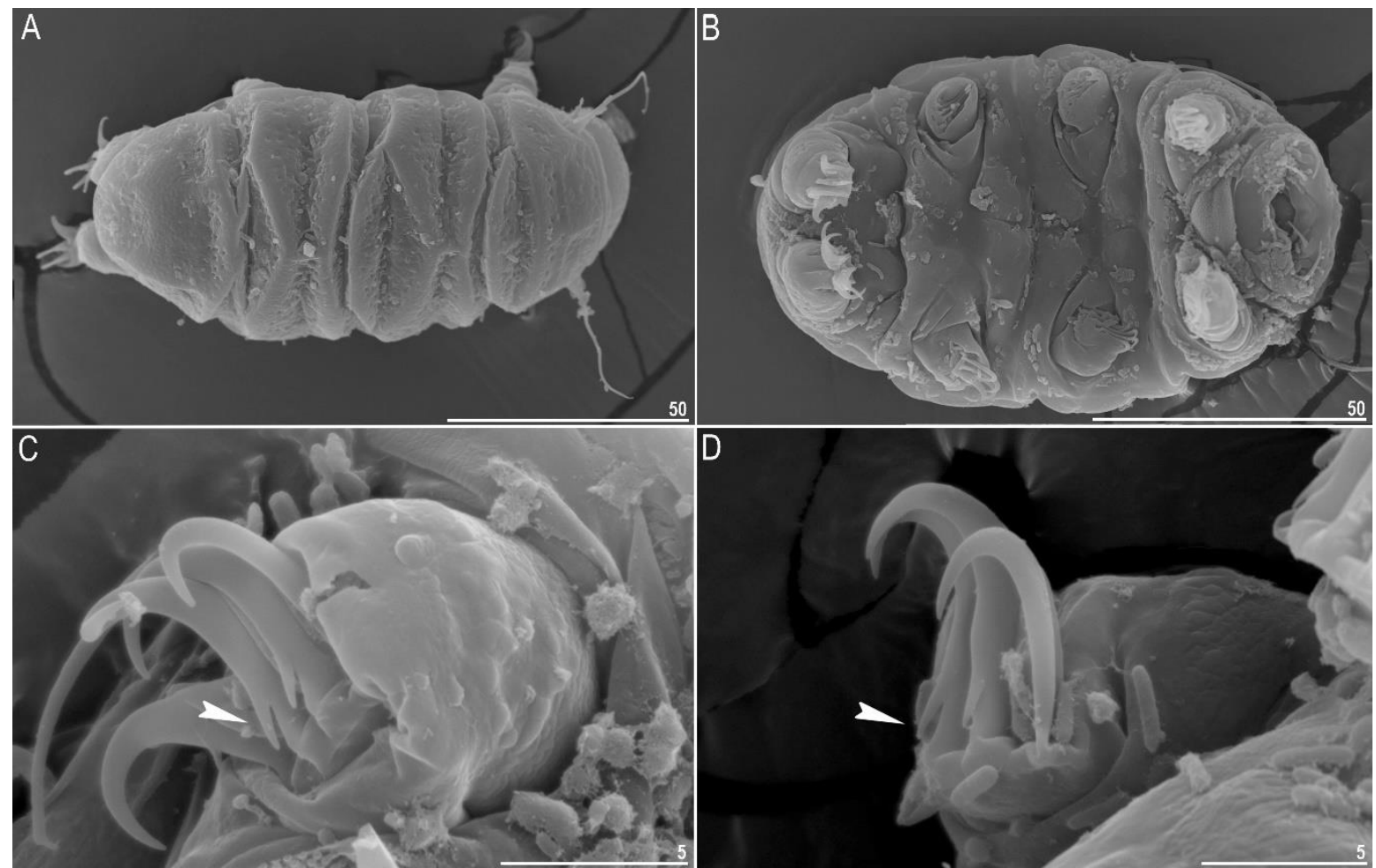

Figure 1. Bryodelphax sp. nov.: A - Dorsal view, adult (SEM); B - Ventral view, adult (SEM); C Claws of leg I (SEM), arrowhead indicates spur; D - Claws of leg IV (SEM), arrowhead indicates spur. Scale bars in $\mu \mathrm{m}$.

\section{Macrobiotus sp. nov.}

\section{DNA sequences}

We obtained good quality sequences for the applied molecular markers:

18S rRNA: single sequence; 553 bp long;

28S rRNA: single sequence; 721 bp long;

ITS-2: single sequence; 350 bp long; 
COI: single sequence; 609 bp long;

Based on COI molecular data, Macrobiotus sp. nov. is most similar to Mac. canaricus Stec, Krzywański \& Michalczyk, 2018 (p-distance 17\%).

Short diagnosis: Macrobiotidae with Y-shaped claws. Colour white. Eyes present. Cuticle with small pores $0.6-1.8 \mu \mathrm{m}$ in diameter. Two macroplacoids and a relatively small microplacoid close to the last macroplacoid. The oral cavity armature of the hufelandi-type with first and the second band composed of numerous minute teeth and a system of three dorsal and three ventral transverse ridges. Macroplacoid length sequence $2<1$. Granulation present on all legs. Eggs spherical, ornamented, white and laid freely. Egg chorion reticulated (hufelandi type). Processes in the shape of inverted concave cups with terminal discs (diameter $3.2-6.1 \mu \mathrm{m}$ ). Morphologically, Macrobiotus sp. nov. is most similar to Mac. porifini [25] and differs from it by higher mean buccal tube length, higher mean stylet support insertion point, higher mean buccal tube external and internal width, higher $p t$ of placoid row, higher egg bare and egg full diameter.

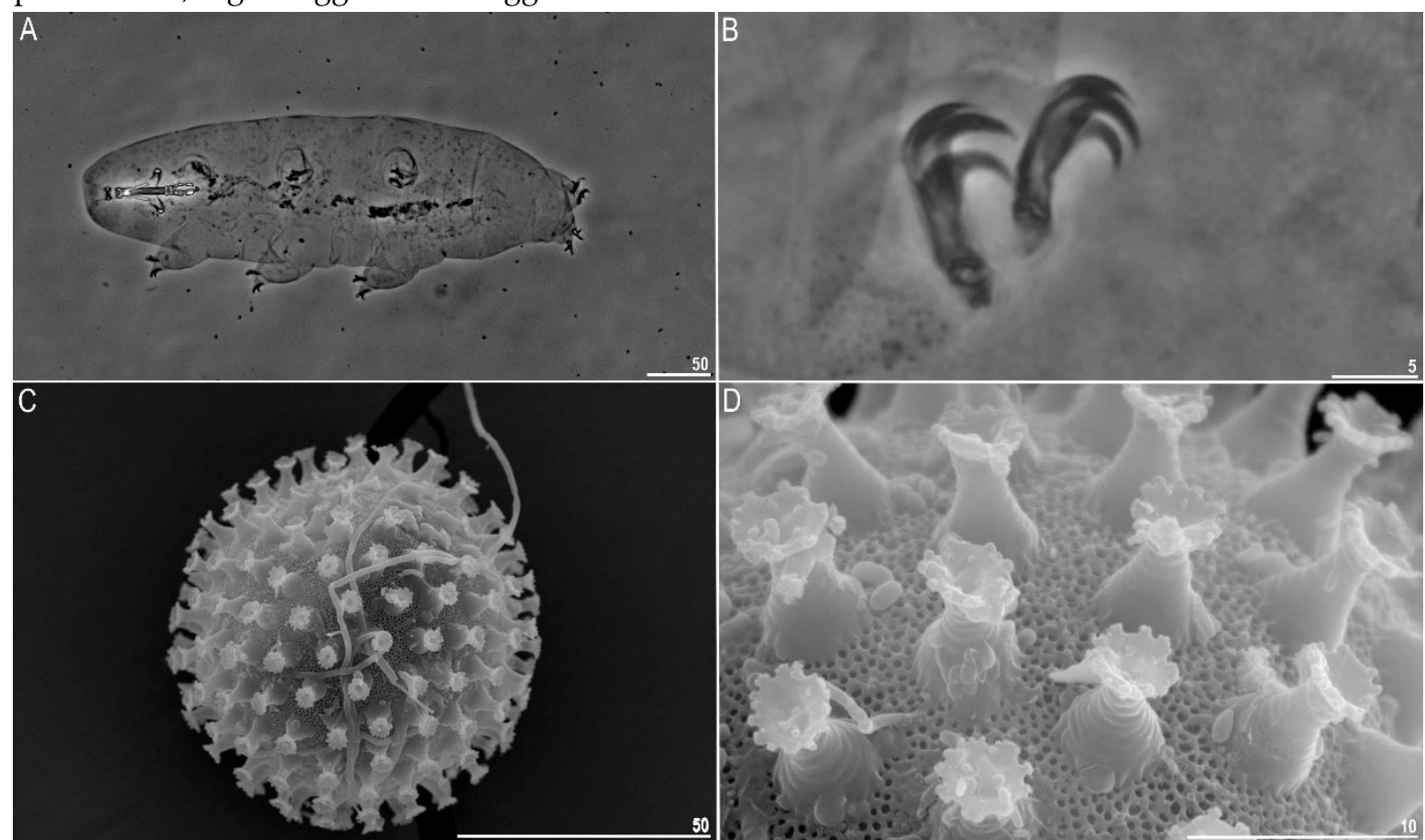

Figure 2. Macrobiotus sp. nov.: A - Dorsal view, adult (PCM); B - Claws of leg II (PCM); C - Egg general view (SEM); D - Egg surface and egg processes (SEM). Scale bars in $\mu \mathrm{m}$.

\section{Mesobiotus skorackii Kaczmarek et al., 2018}

\section{DNA sequences}

We obtained good quality sequences for the applied molecular markers:

18S rRNA: two sequences; $667-715$ bp long;

28S rRNA: single sequence; 735 bp long;

COI: single sequence; 631 bp long;

Based on COI molecular data, Mesobiotus skorackii is most similar to Mesobiotus occultatus Kaczmarek et al., 2018 (p-distance 20\%).

Short diagnosis: Macrobiotidae with Y-shaped claws. Colour white. Eyes present. Cuticle smooth and without pores. Three roundish macroplacoids and a relatively large microplacoid close to the 
last macroplacoid. The oral cavity armature well developed and composed of three bands of teeth (harmsworthi type). Macroplacoid length sequence $2<3<1$. Granulation hardly visible on legs I-III, whereas on legs IV always clearly visible. Eggs laid freely, white, spherical and ornamented, with short wide cones and delicate areolation. Egg processes reticulated with mesh and surrounded by six areolae delimited by thin brims which are often discontinuous, thus areolae are not always fully formed (semi-areolation).
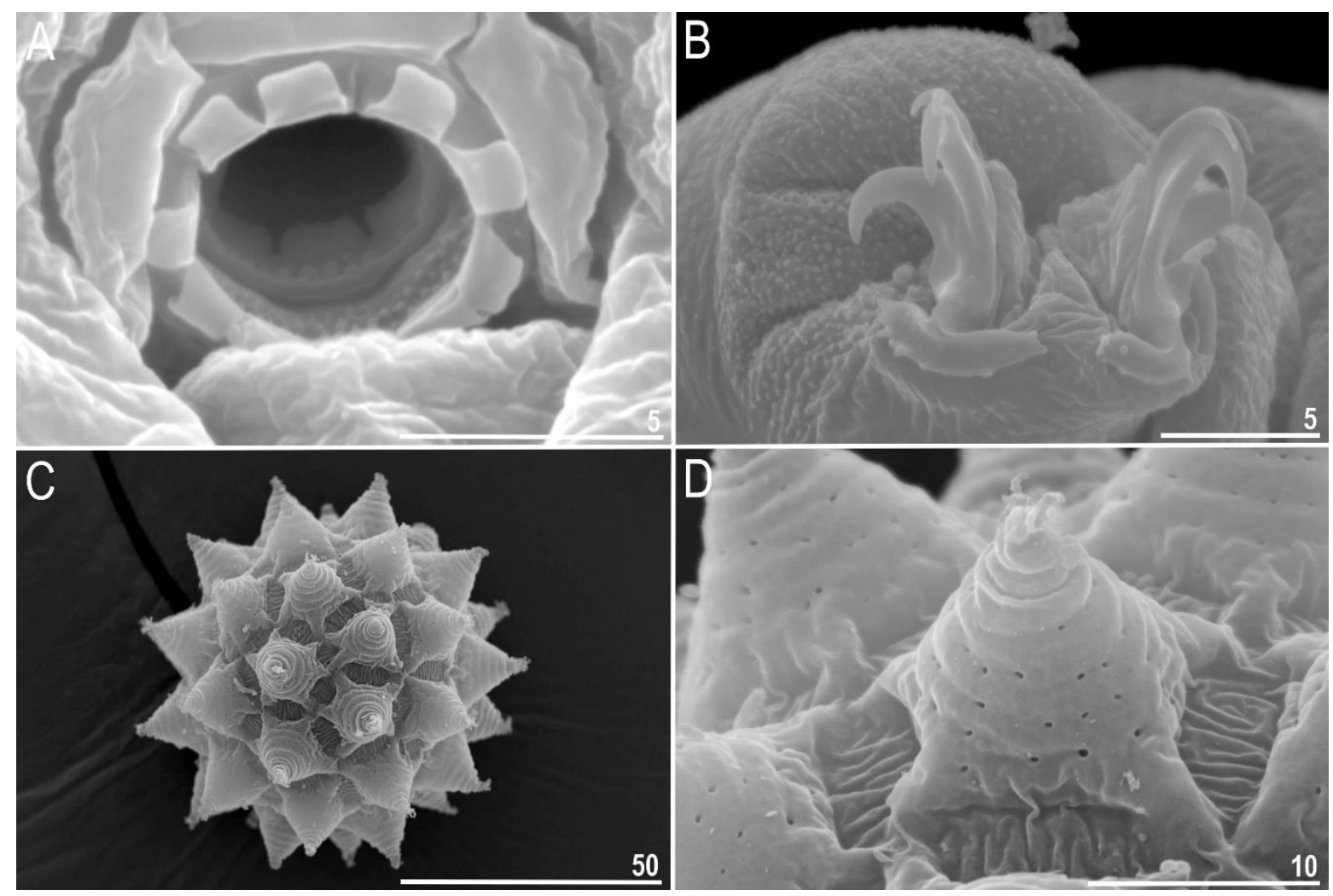

Figure 3. Mesobiotus skorackii.: A - Oral cavity amature, adult (SEM); B - Claws of leg IV (SEM); C - Egg general view (SEM); D - Egg surface and egg processes (SEM). Scale bars in $\mu \mathrm{m}$.

\section{Paramacrobiotus sp. nov.}

Diagnosis: Macrobiotidae with Y-shaped claws. Colour white. Eyes absent. Cuticle smooth and without pores. Oral cavity armature typical with three bands of teeth. Macroplacoid length sequence $2<1<3$. Granulation present on all legs. Smooth lunules under all claws. Eggs laid freely, white, spherical with processes in shape of short wide cones ended with flat and granulated cap. Egg shells areolated with ca. 10 areolae around each process and internal surface of the areoles with pores (richtersi type). Morphologically, Paramacrobiotus sp. nov. is most similar to Pam. gerlachae (Pilato, Binda \& Lisi [26]) but it differs from it by longer placoid row, longer macroplacoid row, higher $p t$ of microplacoid, larger primary branches of legs I-III and larger anterior and posterior primary branches of leg IV. 

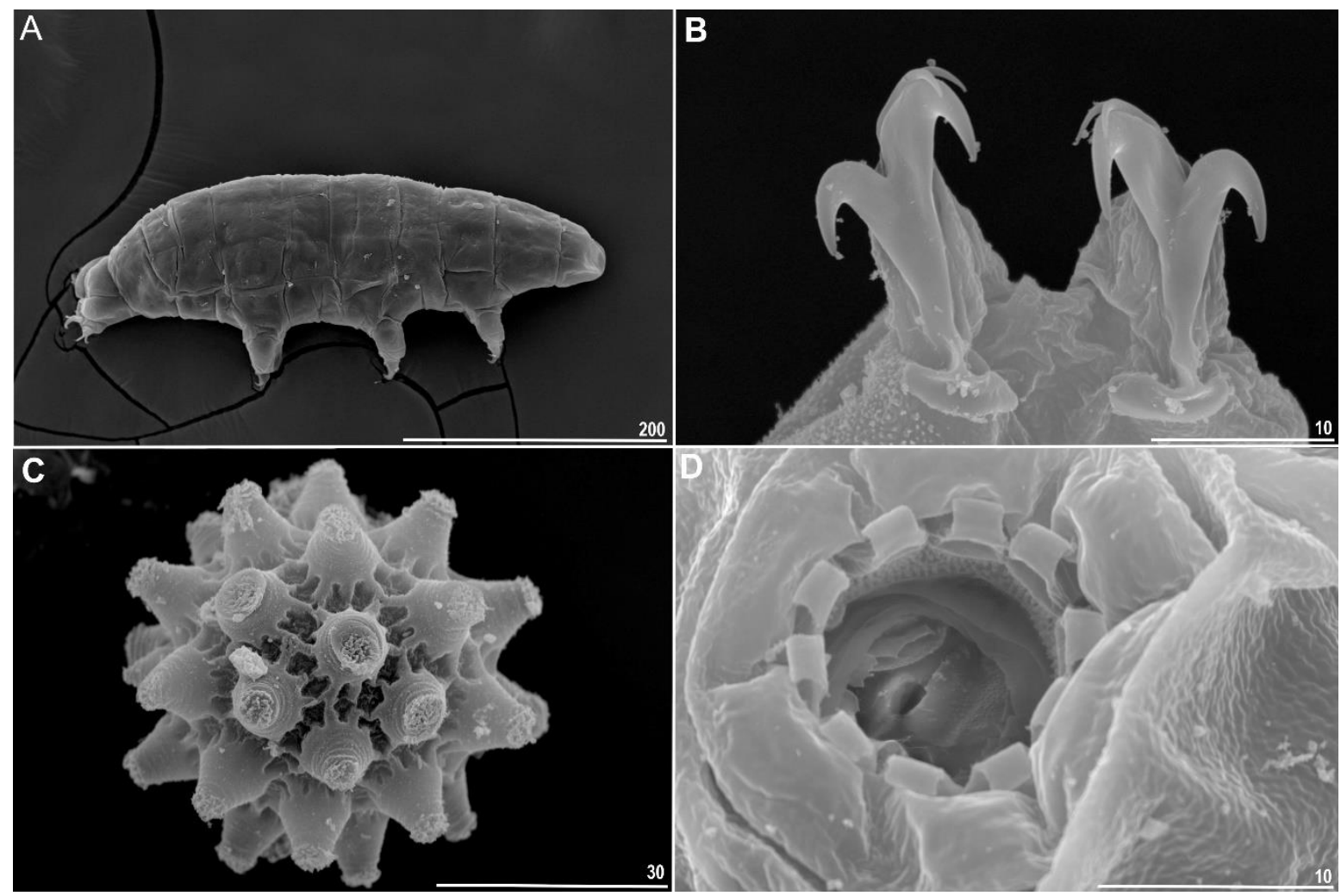

Figure 4. Paramacrobiotus sp. nov.: A - Dorsal view, adult (SEM); B - Claws of leg IV (SEM); C Egg general view (SEM); D - Oral cavity amature (SEM). Scale bars in $\mu \mathrm{m}$.

\section{Conclusions}

Bryodelphax sp. nov., Macrobiotus sp. nov., Mesobiotus skorackii and Paramacrobiotus sp. nov. were found in a single moss sample collected in Canada. We described all these species using an integrative approach. These four species discovery brings the current number of tardigrade taxa in Canada to ca. 124.

Taking into consideration that in the present study, in one analysed sample we found three species new for science and one new regordmeans that with hight probability we can assume that many new species will be discovered in this region in the future.

Acknowledgments: Studies have been partially conducted in the framework of activities of BARg (Biodiversity and Astrobiology Research group). Milena Roszkowska and Pushpalata Kayastha is a scholarship holder of 506000/604/4102000000BW002029 (GDWB-06/2019) \& (GDWB-08/2020) and Passport to the future Interdisciplinary doctoral studies at the Faculty of Biology, Adam Mickiewicz University in Poznań (No: POWR.03.02.00-00-I006/17).

Author's Contribution: MR and ŁK collected the sample. PK conceived the study. PK examined the sample, provided measurements and photographs of new species. MR provided photographs of new species and prepared the figures. MM collected and analysed molecular data. MG prepared SEM photographs. PK, MR, MM drafted the manuscript. $€ K$ supervised the entire process and drafted the manuscript.

Conflicts of Interest: The authors declare no conflict of interest.

\section{References}

1. Ramazzotti, G. ; Maucci, W. Il Phylum Tardigrada. III edizione riveduta e aggiornata. Mem. Ist. Ital. Idrobiol., Pallanza, 1983, 41, 1-1012. 
2. Beasley, C.W. The phylum Tardigrada. 3rd Edition by G. Ramazzotti and W. Maucci. English Translation. Published by the translator Clark Beasley, Abilene 1995.

3. Nelson, D.R.; Guidetti, R.; Rebecchi, L.; Kaczmarek, Ł.; McInnes, S. Phylum Tardigrada. In Thorp and Covich's Freshwater Invertebrates; Elsevier 2020, 505-522, ISBN 9780128042250.

4. Guidetti, R.; Bertolani, R.B. Tardigrade Taxonomy: An updated check list of the taxa and a list of characters for their identification. Zootaxa 2005, 845, 1, https://doi.org/10.11646/zootaxa.845.1.1

5. Degma, P.; Guidetti, R. Notes to the current checklist of Tardigrada. Zootaxa 2007, 1579, 41-53, https://doi.org/10.11646/zootaxa.1579.1.2

6. Vicente, F.; Bertolani, R. Considerations on the taxonomy of the Phylum Tardigrada. Zootaxa 2013, 3626, 245-248, https://doi.org/10.11646/zootaxa.3626.2.2

7. Degma, P.; Bertolani, R.; Guidetti, R. Actual checklist of Tardigrada species. 2009-2020 (Version 37: Edition: 08-07-2020). Available from: https://iris.unimore.it/retrieve/270444/Actual\%20checklist $\% 20$ of $\% 20$ Tardigrada $\% 2037$ th $\% 20$ Edition $\%$ 2008_07_20.pdf

8. Collins, M.; Goudie, I. The Tardigrade and associated micrometazoa of the textured lungwort lichen, lobariascrobiculata, in Eastern Newfoundland, Canada. JALS 2020, 7, https://doi.org/10.30845/jals.v7n2p2

9. Kaczmarek, Ł.; Michalczyk, Ł.; McInnes, S.J. Annotated zoogeography of non-marine Tardigrada. Part III: North America and Greenland. Zootaxa, 2016, 4203, 1, 1-249, https://doi.org/10.11646/zootaxa.4203.1.1

10. Kaczmarek, Ł.; Zawierucha, K.; Buda, J.; Stec, D.; Gawlak, M.; Michalczyk, Ł.; Roszkowska, M. An integrative redescription of the nominal taxon for the Mesobiotus harmsworthi group (Tardigrada: Macrobiotidae) leads to descriptions of two new Mesobiotus species from Arctic. PLoS ONE 2018, 13, e0204756, https://doi.org/10.1371/journal.pone.0204756

11. Grothman, G.T. Tardigrades of Fish Creek Provincial Park, Alberta, Canada: A preliminary survey. Can. Field Nat. 2011, 125, 22, https://doi.org/10.22621/cfn.v125i1.1117

12. Roszkowska, M.; Stec, D.; Gawlak, M.; Kaczmarek, Ł. An integrative description of a new tardigrade species Mesobiotus Romani sp. nov. (Macrobiotidae: harmsworthi group) from the ecuadorian Pacific coast. Zootaxa 2018, 4450, 550, https://doi.org/10.11646/zootaxa.4450.5.2.

13. Grobys, D.; Roszkowska, M.; Gawlak, M.; Kmita, H.; Kepel, A.; Kepel, M.; Parnikoza, I.; Bartylak, T.; Kaczmarek, Ł. High Diversity in the Pseudechiniscus suillus-facettalis complex (Heterotardigrada: Echiniscidae) with remarks on the morphology of the genus Pseudechiniscus. Zool. J. Linn. Soc. 2020, 188, 733-752, https://doi.org/10.1093/zoolinnean/zlz171.

14. Kaczmarek, Ł.; Grobys, D.; Kulpa, A.; Bartylak, T.; Kmita, H.; Kepel, M.; Kepel, A.; Roszkowska, M. Two new species of the genus Milnesium Doyère, 1840 (Tardigrada, Apochela, Milnesiidae) from Madagascar. ZK 2019, 884, 1-22, https://doi.org/10.3897/zookeys.884.29469.

15. Folmer, O.; Black, M.; Hoeh, W.; Lutz, R.; Vrijenhoek, R. DNA Primers for amplification of mitochondrial cytochrome c oxidase subunit I from diverse metazoan invertebrates. Mol. Mar. Biol. Biotechnol. 1994, 3, 294-299.

16. Sands, C.J.; McInnes, S.J.; Marley, N.J.; Goodall-Copestake, W.P.; Convey, P.; Linse, K. Phylum Tardigrada: an "individual" approach. Cladistics 2008, 24, 861-871, https://doi.org/10.1111/j.1096$\underline{0031.2008 .00219 . x}$ 
17. Mironov, S.V.; Dabert, J.; Dabert, M. A new feather mite species of the genus Proctophyllodes Robin, 1877 (Astigmata: Proctophyllodidae) from the Long-tailed Tit Aegithalos caudatus (Passeriformes: Aegithalidae)-morphological description with DNA barcode data. Zootaxa 2012, 3253, 54, https://doi.org/10.11646/zootaxa.3253.1.2

18. White, T. J.; Bruns, T.; Lee, S.; Taylor, J. PCR protocols: a guide to methods and application. AP, San Diego, California, 1990, 315-322.

19. Kaczmarek, Ł.; Roszkowska, M.; Poprawa, I.; Janelt, K.; Kmita, H.; Gawlak, M.; Fiałkowska, E; Mioduchowska, M. Integrative description of bisexual Paramacrobiotus experimentalis sp. nov. (Macrobiotidae) from republic of Madagascar (Africa) with microbiome analysis. Mol. Phylogenet. Evol. 2020, 145, 106730 https://doi.org/10.1016/j.ympev.2019.106730

20. Altschul, S.F.; Gish, W.; Miller, W.; Myers, E.W.; Lipman, D.J. Basic Local Alignment Search Tool. J. Mol. Biol. 1990, 215, 403-410, https://doi.org/10.1016/S0022-2836(05)80360-2

21. Hall, T.A. BioEdit: a user-friendly biological sequence alignment editor and analysis program for Windows 95/98/NT. Nucleic Acids Symp., 1999, 41, $95-98$. http://brownlab.mbio.ncsu.edu/JWB/papers/1999Hall1.pdf

22. Rice, P.; Longden, I.; Bleasby, A. EMBOSS: The European Molecular Biology Open Software Suite. Trends Genet. 2000, 16, 276-277, https://doi.org/10.1016/S0168-9525(00)02024-2

23. Goujon, M.; McWilliam, H.; Li, W.; Valentin, F.; Squizzato, S.; Paern, J.; Lopez, R. A new bioinformatics analysis tools framework at EMBL-EBI. Nucleic Acids Res. 2010, 38, W695-W699, https://doi.org/10.1093/nar/gkq313

24. Kumar, S.; Stecher, G.; Li, M.; Knyaz, C.; Tamura, K. MEGA X: Molecular Evolutionary Genetics Analysis across Computing Platforms. Mol. Biol. Evol. 2018, 35, 1547-1549, https://doi.org/10.1093/molbev/msy096

25. Kuzdrowska, K.; Mioduchowska, M.; Gawlak, M.; Bartylak, T.; Kepel, A.; Kepel, M.; Kaczmarek, Ł. Integrative description of Macrobiotus porifini sp. nov. (Macrobiotidae; hufelandi group) from Madagascar with phylogenetic analysis of hufelandi group. Eur. Zool. J. 2021 (in press)

26. Pilato, G.; Binda, M.G.; Lisi, O. Notes on tardigrades of the Seychelles with the description of three new species. Ital. J. Zool. 2004, 71, 171-178, https://doi.org/10.1080/11250000409356569 